\title{
Patterns of binge drinking among adults in urban and rural areas of Pha-An township, Myanmar
}

Saw Morgan Soe Win' ${ }^{1}$, Chitlada Areesantichai ${ }^{2}$.

${ }^{1}$ College of Public Health Sciences, Chulalongkorn University, Bangkok, Thailand; ${ }^{2}$ Drug Dependence Research Centre, World Health Organization Collaboration Centre for Research and Training in Drug Dependence (WHOCC), College of Public Health Sciences, Chulalongkorn University, Bangkok, Thailand.

Correspondence email: sawmorgan@gmail.com

\begin{abstract}
Binge alcohol drinking is a dangerous pattern of alcohol consumption that may result in intoxication and death. In Myanmar, no prior study for binge drinking has been conducted. This study aims to assess the alcohol consumption among adults in urban and rural areas of Pha-An Township, the capital city of the Karen state in South East Myanmar.
\end{abstract}

Method: This study was conducted via face-to-face interviews among urban (264) and rural (114) participants . The participants who consume alcohol were assessed for their alcohol drinking patterns by using the Time Line Follow Back (TLFB) method. The collected data was analysed using the Chi-square test.

Results: The result indicated that about $60 \%$ had previously consumed alcohol, and half of them reported practicing binge drinking. The largest age group of binge drinkers was 25-44. The majority of the participants (over 70\%) started alcohol consumption as teens, especially at the age between 15-20 years, and the most common type of alcohol for their first time use was toddy (54.4\%). The onset of alcohol consumption, occupations and other substances like smoking and betel chewing, are associated with binge drinking.

Conclusion: It is concluded that $17.7 \%$ of the total study population have practiced binge drinking and it peaks in the age group of 25-44 years.

Recommendation: It is strongly recommended that a more in-depth research is carried out regarding binge drinking. 


\section{نمطالثرب المفرط بين البالغين في المدن و الأرياف بمقاطعة "فا آن" بميانمار}

$$
\text { صو مورجن صو وين* و تشيتلادا آريسانتيكاي (دكتور اه) }
$$

الملخص:

للحة عن الموضوع: يعتبر الإستهلاك المفرط للكحول شكل خطير من أثكال الثرب و قاب قد يؤدي إلى تسمح

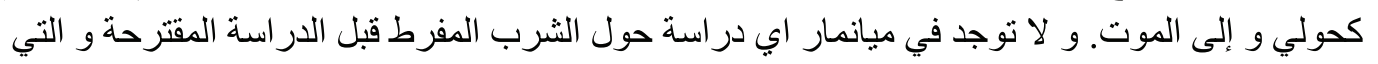

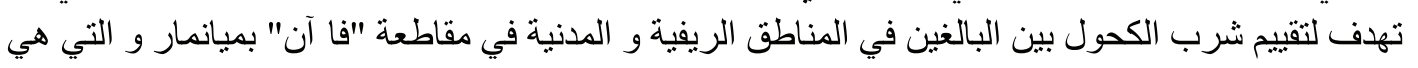
عاصمة ولاية "كارن" و التي تقع في الجزء الجنوب شئن شرقي من ميانمار.

الطريقة: أجريت هذه الدراسة عن طريق إقامة حوار ات وجها لوجنه مع 264 مشارك يقطنون الأرياف و

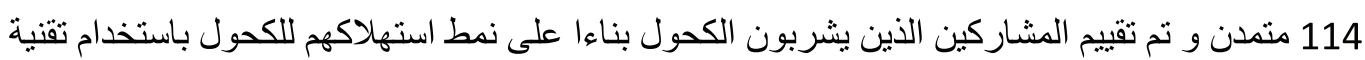
المتابعة الزمنية الرجعية و تم تحليل البيانات المحصل عليها عن طريق استخدام تقنية إختبار "كاي مربع".

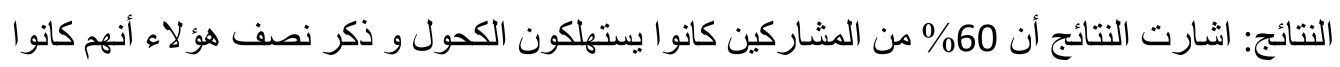

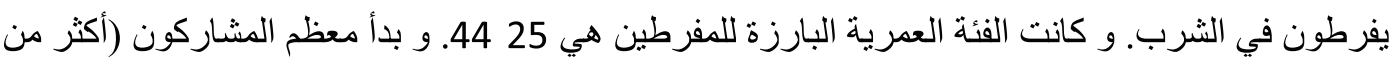

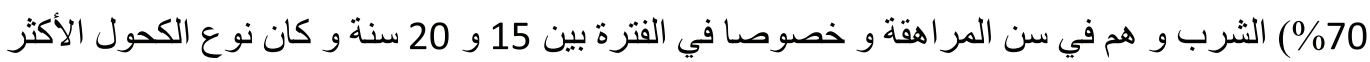

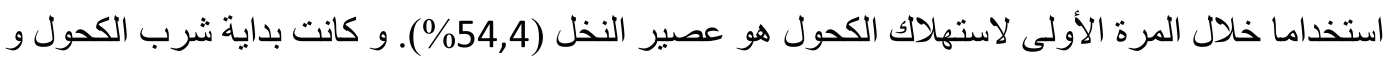

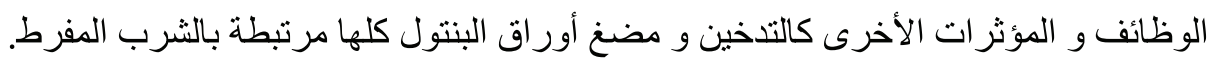

الخلاصة: إستخلص أن 17,7\% من العينة التي تمت معاينتها يشربون بشكل مفرطو لوحظت الذروة بين

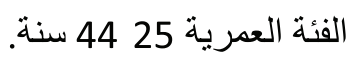

توصية: ننصح بقوة أن تجرى أبحاث معقة أخرى حول موضوع الإفر اط في استهلاك الكحول.

Keywords: Adults, Urban and rural, Binge drinking, First time drinking age and type

\section{Introduction}

In 2005, the global average consumption of pure alcohol was $6.13 \mathrm{~L}$ (over 15 years). Since 1990, the worldwide recorded Adult Per Capita (APC) consumption has remained stable at around 4.3 to $4.7 \mathrm{~L}$ of pure alcohol in all World Health Organization (WHO) regions. The alcohol consumption in Europe rose again to around $9.5 \mathrm{~L}$ after a decrease in the early $1990 \mathrm{~s}$, while in America it stabilised at 6.7 L. By the end of the 20th Century, total APC rose in the Western Pacific region. About 30\% of total APC for worldwide adult consumption is unrecorded. A total of $28.6 \%$ of the unrecorded APC is homemade, illegally produced or outside the control of the government. 
In the developed world (e.g. Europe) the alcohol consumption was highest when compared with developing countries. However, high income is not always directly related to high alcohol drinking and its related risks (WHO 2011).

The annual report of 2.5 million deaths is the result of the harmful effects of alcohol (WHO 2005). Harmful effects of alcohol have been recognised as a major risk of morbidity and mortality (UN 2006). Harmful alcohol use plays the third largest contributor for Global Burden of Disease (GBD) which results in 3.8\% of all deaths and $4.6 \%$ of all Disability Adjusted Life Years Lost (DALYs) ( (Rehm et al., 2009).

In South East Asia, alcohol consumption is increasing gradually, and the total APC is 2.20. The unrecorded APC is 1.52, and this provides the basis for the 69\% of total APC for South East Asia (WHO 2011).

In Myanmar, while the total population is over 48 million, the population over 15 years is $73 \%$, and the population in urban areas is $31 \%$. The World Bank ranks Myanmar as a low income country. Total APC for Myanmar is 0.9 (recorded 0.5 and unrecorded 0.4 ). Therefore, $80 \%$ of the total APC of Myanmar is contributed by unrecorded APC. For the consumers only, the total APC is 7.22 (male 7.43 and female 4.44). The percentage of heavy episodic drinkers among males is 18.7 , and for females it is $3.3(\mathrm{WHO}, 2011)$ (UN, 2006).

The Pha-An township, which is the capital city of Karen State, is situated beside the Asia Highway. It is an important trading town between Thailand and Myanmar, and is also the central entry city to the Karen state. Generally, alcohol consumption is highest among adults and starts to increase from the age group of 18 to 24 years, which is the highest age group for alcohol consumption. It then starts to reduce among the age group of 55 to 64 years (CBS 2003).

This study aims to assess the pattern of binge alcohol drinking among adults from both rural and urban areas of the Pha-An Township, in the Karen state, Myanmar, and to obtain information on its alcohol consumption patterns.

\section{Material and Method}

\section{Study Design}

A cross-sectional study design was used for data collection in the study area. 


\section{Sample and data collection}

The sample size for this study was calculated using the Krejcie Morgan formula with 378 as the most suitable number of respondents. The target population is adults (19-65 years) from both urban and rural areas of the Pha-An township. This study is a household survey and the wards and villages from the township were chosen through cluster sampling. There are eight wards from urban areas and three villages in a nearby town. Four wards from urban areas and two villages from rural areas were chosen for data collection. The respondents were selected based on the inclusion criteria of: 1) anyone aged from 19 to 65 years, 2) voluntary par ticipants, 3) people who have stayed in the study area for at least six months before the interview and 4) people who speak Burmese. The exclusion criteria for this study were: 1) people with mental illness who could not understand the questionnaire and could not answer properly and 2) physically ill patients with poor health and those who had uncomfortable conditions for interviewing time and answering questions. The data collection was carried out via face-to-face interviews in March 2014.

\section{Measurement tools}

A structured questionnaire was used, including socio-demographic characteristics i.e. age, gender, onset of alcohol drinking, occupation etc. TLFB was used in this study to assess detailed alcohol consumption patterns in the last two weeks before the interview (Sobell and Sobell, 1992). The measurement tools were approved by the ethical committee of the Chulalongkorn University (COA No.036/2014).

\section{Data analysis}

Chi-square was used to determine the statistical significance of the association between the demographic characteristics and binge drinking.

\section{Results}

Binge drinking is defined as consuming more than five standard drinks for men and four standard drinks for women on one occasion, and it could be explored by using TLFB. The participants were divided into two main groups: urban and rural, and the demographic characteristics were described in numbers and percentages in each category as shown in Table 1 . A total of $70 \%$ (264) of the participants were from urban areas and 30\% (114) participants were from rural areas. The participants were divided again into three groups according to age range: 19 to 24 years, 25 to 44 years and 45 to 64 years. The number of participants from each age group and gender were similar. 
The largest number of participants in this study was Buddhists (237 participants), followed by Christians (132 participants). Only a small number consisted of other religions. The majority of participants were the Karen and Burmese, not only in this study but also in the population of the whole study area. The total number of participants from the Karen state in this study was 252, and 111 were Burmese. Only a few who were involved in this study were Indians and Chinese. About $1 / 3$ of the participants were graduates. Approximately $36 \%$ of the study population had passed only high school level. Almost half the participants (176) were married, followed by singles (160 participants). The number of unemployed participants was $126(33.3 \%)$ of the study population. Various types of occupations were recorded among the employed participants. A total of $20.6 \%$ ( 78 participants) owned their local business. Obviously, the unemployed did not have any income. Approximately $1 / 3$ of the employed respondents $(31.8 \%, 120$ participants) had a monthly income of USD 1 to USD 99, and 25.4\% (96 participants) had an income of USD 100 to USD 299.

\section{Table 1. Demographic characteristics of adults from urban and rural areas of Pha-An Township}

\begin{tabular}{|c|c|c|c|c|}
\hline \multirow[t]{2}{*}{ Variables } & \multicolumn{2}{|c|}{$\begin{array}{l}\text { Urban } \\
n(\%) n=264\end{array}$} & \multicolumn{2}{|c|}{$\begin{array}{l}\text { Rural } \\
\text { n ( \% ) n=114 }\end{array}$} \\
\hline & $\begin{array}{l}\text { Male } \\
n=143\end{array}$ & $\begin{array}{l}\text { Female } \\
n=121\end{array}$ & $\begin{array}{l}\text { Male } \\
n=61\end{array}$ & $\begin{array}{l}\text { Feale } \\
n=53\end{array}$ \\
\hline \multicolumn{5}{|l|}{ Age ( Years ) } \\
\hline $19-24$ & $49(34.3 \%)$ & $39(32.2)$ & $21(34.4 \%)$ & $15(28.3 \%)$ \\
\hline $25-44$ & $51(35.7 \%)$ & $41(33.9 \%)$ & $18(29.5 \%)$ & $26(49.1 \%)$ \\
\hline $45-65$ & $43(30.0 \%)$ & $41(33.9 \%)$ & $22(36.1 \%)$ & $12(22.6 \%)$ \\
\hline \multicolumn{5}{|l|}{ Religion } \\
\hline Buddhist & $95(66.4 \%)$ & $60(49.6 \%)$ & $46(75.4 \%)$ & $36(67.9 \%)$ \\
\hline Christian & $43(30.1 \%)$ & $57(47.1 \%)$ & $15(24.6 \%)$ & $17(32.1 \%)$ \\
\hline Hindu & $2(1.4 \%)$ & $2(1.6 \%)$ & $0(0 \%)$ & $0(0 \%)$ \\
\hline Islam & $3(2.1 \%)$ & $2(1.6 \%)$ & $0(0 \%)$ & $0(0 \%)$ \\
\hline
\end{tabular}




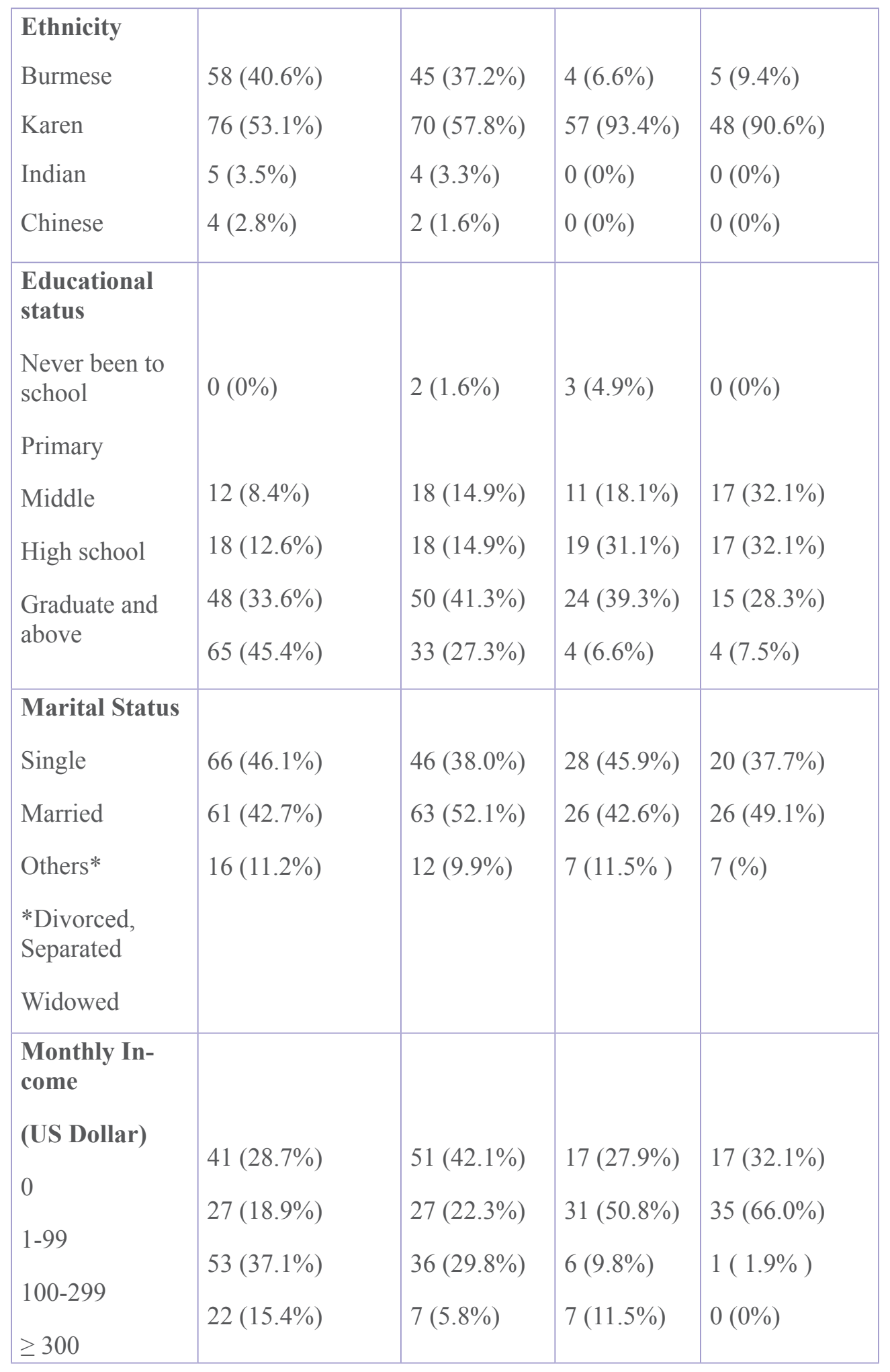




\begin{tabular}{|l|l|l|l|l|}
\hline $\begin{array}{l}\text { Occupation } \\
\text { Government } \\
\text { sector employ- } \\
\text { ees }\end{array}$ & $22(13.4 \%)$ & $16(13.2 \%)$ & $1(1.6 \%)$ & $1(1.9 \%)$ \\
$\begin{array}{l}\text { Private sector } \\
\text { employees }\end{array}$ & $17(11.9 \%)$ & $8(6.6 \%)$ & $6(9.9 \%)$ & $0(0 \%)$ \\
$\begin{array}{l}\text { Businessmen } \\
\text { Farmers }\end{array}$ & $41(28.7 \%)$ & $19(15.7 \%)$ & $9(14.8 \%)$ & $9(17.0 \%)$ \\
$\begin{array}{l}\text { Vendors } \\
\text { Unemployed }\end{array}$ & $91(0 \%)$ & $0(0 \%)$ & $25(40.9 \%)$ & $11(20.8 \%)$ \\
$\begin{array}{l}\text { Others } \\
\text { (Taxi drivers, } \\
\text { daily workers } \\
\text { etc.) }\end{array}$ & $13(9.1 \%)$ & $21(17.4 \%)$ & $1(1.6 \%)$ & $13(24.5 \%)$ \\
\hline
\end{tabular}

Most of the participants ( $60 \%$ or 215 participants) were used to alcohol consumption and among them, 31.1\% (67 participants) were hooked on binge drinking, which was commonly seen in the age group of 25-44 years olds.

Table 2. Binge drinking practice as per age group and gender from urban and rural areas of Pha_AnTwonship $n=67$

\begin{tabular}{|c|c|c|}
\hline $\begin{array}{l}\text { Age Group } \\
\text { (In years) } \\
\end{array}$ & $\begin{array}{l}\text { Urban } \\
\mathrm{n}(\%) \mathrm{n}=47\end{array}$ & $\begin{array}{l}\text { Rural } \\
\text { n ( \% }) \quad n=20\end{array}$ \\
\hline $19-24$ & $5(10.6 \%)$ & $10(50.0 \%)$ \\
\hline $25-44$ & $29(61.7 \%)$ & $6(30.0 \%)$ \\
\hline $45-65$ & $13(27.7 \%)$ & $4(20.0 \%)$ \\
\hline \multicolumn{3}{|c|}{$\begin{array}{l}\text { Onset age of alcohol } \\
\text { consumption } \\
(\mathrm{yr})\end{array}$} \\
\hline $10-15$ & $4(8.5 \%)$ & $0(0 \%)$ \\
\hline $16-20$ & $32(68.1 \%)$ & $17(85.0 \%)$ \\
\hline $21-25$ & $6(12.8 \%)$ & $2(10.0 \%)$ \\
\hline $26-30$ & $2(4.2 \%)$ & $0(0 \%)$ \\
\hline$>30$ & $3(6.4 \%)$ & $1(5.0 \%)$ \\
\hline
\end{tabular}




\begin{tabular}{|l|l|l|}
\hline $\begin{array}{l}\text { Occupation } \\
\text { povernment sector em- }\end{array}$ & $9(19.1 \%)$ & $0(0 \%)$ \\
Private sector employee & $4(8.5 \%)$ & $3(15.0 \%)$ \\
Businessmen & $20(42.6 \%)$ & $5(25.0 \%)$ \\
Farmers & $0(0 \%)$ & $11(55.0 \%)$ \\
Vendors & $7(14.9 \%)$ & $0(0 \%)$ \\
Unemployed & $0(0 \%)$ & $1(5.0 \%)$ \\
Other & $7(14.9 \%)$ & $0(0 \%)$ \\
(Taxi driver, daily work- & & $15(75.0 \%)$ \\
ers and etc.) & $42(89.4 \%)$ & $17(85.0 \%)$ \\
\hline Substance use & $32(68.1 \%)$ & \\
Tobacco (Yes) & & \\
Betel nut (Yes) &
\end{tabular}

The alcohol consumption pattern within two weeks prior to the interview for this study was also assessed. The number of participants with 6 to 10 times of binge drinking on weekdays was $31.3 \%$ (21 participants). The frequency of binge drinking on weekdays was higher in urban areas than in rural areas, and also higher among males than females. Binge drinking on weekends was also higher in urban males but the females from rural areas had higher drinking frequency than the males. Considering female drinkers, women from rural areas drank more frequently on weekdays and also on weekends than those from urban areas.

The mean standard level of binge drinkers in the two weeks prior to this study was 49.73 . The mean standard level for male drinkers from urban areas was the highest in the 45-65 year age group; and for the 25-44 year age group from rural areas as mentioned below in Table 3. Females in the age group of 25-44 years old from urban areas have the highest mean standard level of drinking within two weeks. Generally, the frequency of binge drinking was higher in male groups than in the female groups in both urban and rural areas. But relatively, females in the age group of 25-44 years from urban areas and those in 45-66 years from rural areas drank more frequently than males in similar situations ( 7.3 times vs 5 times and 9.5 times vs 1 time respectively). 
Table 3. Amount of total standard drink and frequency of binge drinking in the two weeks prior to study

\begin{tabular}{|c|c|c|c|c|c|c|}
\hline \multirow{2}{*}{$\begin{array}{l}\text { Amount and frequency of } \\
\text { alcohol consumption in } 2 \\
\text { weeks }\end{array}$} & \multicolumn{3}{|l|}{ Urban } & \multicolumn{3}{|l|}{ Rural } \\
\hline & $19-24$ & $25-44$ & $45-65$ & $19-24$ & $25-44$ & $45-65$ \\
\hline Male & $\mathrm{N}=5$ & $\mathrm{~N}=26$ & $\mathrm{~N}=7$ & $\mathrm{~N}=10$ & $\mathrm{~N}=4$ & $\mathrm{~N}=1$ \\
\hline Mean SD for $2 \mathrm{wk}+/$ & 36.2 & 45 & 94.86 & 18.5 & 96 & 34.6 \\
\hline (S.D) & $(37.3)$ & $(40.8)$ & $(62.6 \%)$ & $(7.0)$ & $(87.0)$ & $(0)$ \\
\hline Binge $1+$ time in $2 \mathrm{wks}$ ) & 5 & 5.0 & 10 & 1.8 & 8. & 1 \\
\hline $\begin{array}{l}\text { Mean Standard Drink for } \\
\text { each binge drinking }\end{array}$ & 7.2 & 8.4 & 9.1 & 5.1 & 10.2 & 8 \\
\hline Female & $\mathrm{N}=0$ & $\mathrm{~N}=3$ & $\mathrm{~N}=6$ & $\mathrm{~N}=0$ & $\mathrm{~N}=2$ & $\mathrm{~N}=3$ \\
\hline Mean SD for $2 w k+/$ & 0 & 61 & 51.6 & 0 & 43.2 & 51.5 \\
\hline S.D & & (71.3) & $(58.2)$ & & $(15.9)$ & $(25.1)$ \\
\hline Binge $1+$ time in 2 wks & 0 & 7.3 & 6.6 & 0 & 8 & 9.6 \\
\hline $\begin{array}{l}\text { Mean standard drink for } \\
\text { each binge drinking }\end{array}$ & 0 & 8.3 & 6.9 & 0 & 4.7 & 5.0 \\
\hline
\end{tabular}

There were links between socio-demographic characteristics and binge drinking. The onset of alcohol consumption was strongly associated with binge drinking with a significant level of $<0.05$. There was strong links between occupation and binge drinking and level was $<0.001$. The usage of other substances such as smoking had strong links with binge drinking with a significant level of $<0.001$. Betel nut chewing was also associated with binge drinking and level was $<0.05$. Both smoking and betel nut chewing were significantly associated with binge drinking with a level of $<0.001$. 
Table 4. Association between socio-demographic factors and binge drinking

\begin{tabular}{|c|c|c|c|}
\hline Variables & $\begin{array}{l}\text { Binge Drinking } \\
\text { Yes } \mathbf{n}=\mathbf{6 7}\end{array}$ & $\begin{array}{l}\text { Binge Drinking } \\
\text { No } n=148\end{array}$ & p value \\
\hline $\begin{array}{l}\text { Onset age group } \\
10-15 \\
16-20 \\
21-25 \\
26-30 \\
\text { Above } 30\end{array}$ & $\begin{array}{l}4(6.0 \%) \\
49(73.1 \%) \\
8(11.9 \%) \\
2(3.0 \%) \\
4(6.0 \%)\end{array}$ & $\begin{array}{l}3(2.0 \%) \\
96(64.9 \%) \\
37(25 \%) \\
11(7.4 \%) \\
1(0.7 \%)\end{array}$ & $0.009 *$ \\
\hline $\begin{array}{l}\text { Current age } \\
19-24 \\
25-44 \\
45-65\end{array}$ & $\begin{array}{l}15(22.4 \%) \\
35(52.2 \%) \\
17(25.4 \%)\end{array}$ & $\begin{array}{l}45(30.4 \%) \\
56(37.8 \%) \\
47(31.8 \%)\end{array}$ & 0.139 \\
\hline $\begin{array}{l}\text { Gender } \\
\text { Male } \\
\text { Female }\end{array}$ & $\begin{array}{l}53(79.1 \%) \\
14(20.9 \%)\end{array}$ & $\begin{array}{l}106(71.6 \%) \\
42(28.4 \%)\end{array}$ & 0.247 \\
\hline $\begin{array}{l}\text { Occupation } \\
\text { Government sector } \\
\text { employee }\end{array}$ & $9(13.4 \%)$ & $17(11.4 \%)$ & \\
\hline $\begin{array}{l}\text { Private sector em- } \\
\text { ployee } \\
\text { Businessmen } \\
\text { Farmers } \\
\text { Vendors } \\
\text { Unemployed } \\
\text { Other }\end{array}$ & $\begin{array}{l}7(10.4 \%) \\
25(37.3 \%) \\
11(16.4 \%) \\
7(10.4 \%) \\
1(1.5 \%) \\
7(10.4 \%)\end{array}$ & $\begin{array}{l}17(11.4 \%) \\
29(19.6 \%) \\
14(9.5 \%) \\
14(9.5 \%) \\
43(29.1 \%) \\
14(9.5 \%)\end{array}$ & $0.000 *$ \\
\hline $\begin{array}{l}\text { Education } \\
\text { Never been to school } \\
\text { Primary school level } \\
\text { Middle school level } \\
\text { High school level } \\
\text { Graduate and above }\end{array}$ & $\begin{array}{l}2(3.0 \%) \\
14(20.9 \%) \\
10(14.9 \%) \\
15(22.4 \%) \\
26(38.8 \%)\end{array}$ & $\begin{array}{l}0(0 \%) \\
25(16.9 \%) \\
30(20.2 \%) \\
46(31.1 \%) \\
47(31.8 \%)\end{array}$ & 0.115 \\
\hline
\end{tabular}




\begin{tabular}{|l|l|l|l|}
\hline Other substance use & & \\
Smoking (Yes) & $57(85.1 \%)$ & $60(40.5 \%)$ & $0.000^{*}$ \\
Betel Nut (Yes) & $49(73.1 \%)$ & $86(58.1 \%)$ & $0.035^{*}$ \\
\hline
\end{tabular}

\section{Conclusion}

According to the results of this study, the age group of 25 to 44 years had the highest alcohol consumption and binge drinking level. Alcohol consumption was higher in males than in females. The link between income and alcohol consumption was demonstrated in this study. Educated middle income groups were the highest number of alcohol consumers. Therefore, it can be concluded that those who are educated are more hooked on alcohol.

The incidence of binge drinking in this study area was $17.7 \%$. Generally, the frequency of binge drinking was higher in males than in females. However, middle aged females from urban areas and older females from rural areas were more hooked on binge drinking than males in the situation (7.3 times vs 5 times and 9.5 times vs 1 time respectively).

The age group of 25 to 44 years had a higher number of binge drinking than the other groups. Most of the participants in this group were employed. Their income levels also contributed to their habit of alcohol consumption. The starting age of alcohol consumption was a key contributory factor, and had strong links with binge drinking.

It is suggested in this study that an alcohol control intervention programme is set up i.e. law enforcement to control buying, selling and producing alcoholic beverages. Awareness programmes about the hazards of binge alcohol drinking are strongly recommended.

\section{Discussion}

The results of this study revealed that the binge drinking habit is higher in males than in females and in the age group of 25-44 years olds who are linked with an early start of alcohol consumption. The findings from this study are consistent with a study conducted in Great Britain (Helen and Adrian, 2013). 


\section{Recommendation}

Binge drinking practice is a dangerous pattern of alcohol drinking which leads to health problems as mentioned above. Therefore, it is strongly recommended that awareness of the hazards of binge drinking should be promoted in that area. Further, the status of alcohol consumption in that area as well as other parts of Myanmar needs to be established. To implement programmes of intervention to control alcohol consumption in that area, more information about alcohol consumption is needed. Therefore, detailed studies about alcohol consumption are strongly recommended.

\section{References}

1. CBS. 2003. "Alcohol consumption by age and sex, 2001/2002." [Online]. Available: http://www.cbs.nl/en-GB/menu/themas/vrije-tijd-cultuur/publicaties/artikelen/archief/2003/2003-1227-wm.htm.

2. Helen C, Adrian F. Correlates of Adult Binge Drinking: Evidence from a British Cohort. PLoS ONE. 2013;8(11).

3. Rehm J, Mathers C, Popova S, Thavorncharoensap M, Teerawattananon Y, Patra J. Global burden of disease and injury and economic cost attributable to alcohol use and alcohol-use disorders. Lancet. 2009;373(9682):2223-33.

Doi: http://dx.doi.org/10.1016/S0140-6736(09)60746-7

4. Sobell L, Sobell M. Timeline Follow-Back. In: Measuring Alcohol Consumptioned. R. Litten and J. Allen (ed). Humana Press. 1992;41-72. Doi: http://dx.doi.org/10.1007/978-1-4612-0357-5_3

5. UN. 2006. "Country Profile Myanmar." [Online]. Available: http:// www.who.int/substance_abuse/publications/global_alcohol_report/ profiles/en/.

6. WHO. 2004. "Global status report on alcohol." [Online]. Available: http://www.who.int/substance_abuse/publications/ globalstatusreportalcoholchapters/en/.

7. WHO. 2005. "Public health problems caused by harmful use of alcohol." [Online]. Available: http://www.who.int/nmh/a5818/en/.

8. WHO. 2011. "Global status report on alcohol and health." [Online]. Available: http://www.who.int/substance_abuse/publications/global_ alcohol_report/en/. 